\title{
Een nieuw type coronavirus: MERS-CoV
}

Jaap Maas

In september 2012 is een nieuw type coronavirus ontdekt, het Middle East Respiratory Syndrome Corona Virus (MERS-CoV) genoemd. Op I4 juni 2013 zijn er wereldwijd 60 patiënten met een bevestigde besmetting van MERS-CoV gerappor-

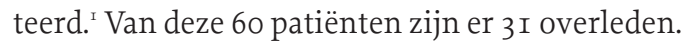
Het gaat dus om een zeer ernstige infectieziekte.

\section{KLINIEK EN TRANSMISSIE}

Alle ziektegevallen zijn terug te leiden naar vier landen in het Midden-Oosten. ${ }^{2}$ De patiënten zijn overwegend mannen, ouder dan 24 jaar. De mediane leeftijd is 56 jaar. Er is nog weinig bekend over de klinische presentatie van MERSCoV. Bij de meeste patiënten presenteert de infectie zich als een ernstig respiratoir beeld. ${ }^{3}$ Op dit moment lijkt de incubatietijd ongeveer I 4 dagen. De transmissieroute is respiratoir, via druppels. Het betreft zeer waarschijnlijk een zoönotische aandoening, maar welke diersoort(en) het reservoir vormen is nog onduidelijk. ${ }^{4}$ Mens-op-menstransmissie is beschreven, maar lijkt beperkt.

\section{VERSPREIDING}

Hoewel MERS-CoV klinisch veel lijkt op SARS, is het epidemiologisch patroon tot nu toe heel anders. Ten tijde van het schrijven van dit artikel was er sprake van sporadische introductie in West-Europa. Het virus lijkt zich niet te verspreiden in de algemene populatie.

Dr. J.J. Maas is bedrijfsarts-epidemioloog, gespecialiseerd in beroepsgerelateerde infectieziekten, werkzaam bij het Nederlands Centrum voor Beroepsziekten, Coronel Instituut, AMC; voorzitter van het Arbomanagementteam (AMT), onderdeel van het Outbreak Management Team van het RIVM.

CORRESPONDENTIEADRES

E-mail: j.j.maas@amc.uva.nl.

\section{AANBEVELINGEN \\ VOOR BEDRIJFSARTSEN}

Indien zich een patiënt meldt met respiratoire ziekteverschijnselen die I4 dagen na terugkeer uit het Midden-Oosten zijn ontstaan, moet de bedrijfsarts denken aan MERS-CoV. Bij een mild ziektebeeld (bijvoorbeeld griepachtige klachten) wordt een expectatief beleid geadviseerd. Bij ernstige pulmonale klachten, of bij een verergering, luidt het advies om contact op te nemen met de huisarts of de internist/infectioloog.

Bij een ongeplande blootstelling van een werknemer met een MERS-CoV-patiënt wordt het volgende algoritme geadviseerd. ${ }^{5}$ Als de blootgestelde werknemer geen acute respiratoire klachten heeft, kan men volstaan met het I4 dagen twee keer per 24 uur opnemen van de temperatuur. Treden er respiratoire klachten op, dan neemt de bedrijfsarts onmiddellijk contact op met de huisarts en/of een internist/infectioloog en de GGD. Voor werknemers in de zorg die met MERS-CoVpatiënten werken, en die gebruik maken van adequate persoonlijke beschermingsmiddelen, zoals adembescherming en handschoenen (zie de WIPrichtlijnen en de KIZA-nieuwsupdate van 5 juni 20I3), wordt passieve monitoring geadviseerd. Dit houdt in dat een werknemer wordt geïnstrueerd zich te melden bij zijn bedrijfsarts, zodra hij respiratoire klachten ontwikkelt.

\section{LITERATUUR}

I. Update: Severe Respiratory illness associated with Middle East Respiratory Syndrome Corona Virus (MERS-CoV) - Worldwide, 2012-2013; Centers for Disease Control and Prevention. MMWR 2013; 62; 7 juni.

2. Groot RJ de, Baker SC, Baric RS, et al. Middle East Respiratory Syndrome Coronavirus (MERS-CoV); announcement of the Coronavirus Study Group. J Virol 20I3; 87: in druk.

3. Roos R. More MERS-CoV cases reported in Saudi Arabia. CIDRAP I4 juni 2013.

4. Petherick A. MERS-CoV: in search of answers. Lancet 20I3; 38I(9883): 2069.

5. Maas J. Update: Middle East Respiratory SyndromeCoronavirus (MERS-CoV). KIZA nieuwsbericht, 5 juni 2013.
MERS-COV, CORONAVIRUS 